\title{
The Regularities in Insufficient Leisure-Time Physical Activity in Poland
}

\author{
Elżbieta Biernat ${ }^{1, *}$ and Sonia Buchholtz ${ }^{2}$ \\ 1 Collegium of World Economy, Warsaw School of Economics, al. Niepodległości 162, \\ Warszawa 02-554, Poland \\ 2 Collegium of Economic Analysis, Warsaw School of Economics, al. Niepodległości 162, Warszawa 02-554, \\ Poland; sb43146@sgh.waw.pl \\ * Correspondence: elzbieta.biernat@sgh.waw.pl; Tel.: +48-603-680-948
}

Academic Editor: Paul B. Tchounwou

Received: 26 April 2016; Accepted: 3 August 2016; Published: 8 August 2016

\begin{abstract}
Background: Insufficient physical activity (PA) has become an increasing risk factor of noncommunicable diseases and an important cause of deaths all over the world. The goal of this paper is to provide an in-depth description of insufficient PA in Poland as well as an examination of some of its correlates. Methods: We take advantage of statistical and econometric (logistic regression) analysis on the basis of a representative survey. Out of 3056 respondents, we analyze the 1260 low-PA ones. Results: The household size is more significant than the household life phase, and only several professions increase the odds of insufficient PA. The influence of socioeconomic status and place of residence is most robust. Gender does not significantly influence insufficient PA. Physical inactivity is concentrated among inhabitants of rural areas and town dwellers, with poor educational profile, and limited labor market opportunities. However, even high socioeconomic status does not completely prevent insufficient activity. Conclusions: Groups at the highest risk of inactivity should be covered by promotional actions first. Their aim should mainly be raising the leisure-time physical activity (LTPA) awareness. To start with, primary forms of activity would be walking, Nordic walking and jogging.
\end{abstract}

Keywords: epidemiology; leisure-time physical activity; demographic and socioeconomic variables; econometric modeling

\section{Introduction}

Since the 1950s insufficient physical activity (PA) has been recognized as a risk factor of noncommunicable diseases (NCDs) [1], and an important cause of deaths all over the world [2]. Its consequences are already common in developed and developing societies [3]. As the adverse trend has become a hot issue, public health strategies all over the world set the objective of increasing PA among the inactive [4]. There are several recommendations of pro-health PA levels [5], as well as types, exercises and frequencies eligible in prophylactics and treating chronic diseases [6,7].

According to the World Health Organization (WHO) data [7], almost one in four (23.3\%) adults in the world has insufficient PA. Its prevalence is not evenly distributed across the globe: in the Americas this share rises to $32.4 \%$, while in Southeast Asia it amounts to $14.7 \%$ of the population. Europe ranks slightly above the average $(24.5 \%)$. These results seem to be underestimating the scale of the phenomenon - as reported by the Center for Disease Control and Prevention and the American College of Sports Medicine (CDC/ACSM), the share of insufficiently activity among adult US citizens exceeds 60\% [8] (WHO: 32.4\%). Eurobarometer estimates the share of Europe citizens who either do not exercise or do it sparsely at $59 \%$ [9]. 
Increasing physical activity, particularly leisure-time physical activity (LTPA), is then a priority task for public health policy-makers worldwide. It has been known that leisure-time effort in the form of training with the duration and frequency recommended for maintaining health may, regardless of the intensity of occupational PA, raise individual capacity and physical fitness [10]. It may also bring significant health benefits, including reduced risk of death due to chronic diseases [11]. In contrast with occupational PA, in LTPA the dynamic body movements vary, and intensive efforts lasting for short periods take place in intervals, interchangeably with active or passive rest [12]. In fact, for many occupations LTPA has become the only chance to counteract sedentary behavior patterns [13].

Unfortunately, 52\% of Poles are physically inactive [9] and their passive attitude towards physical effort coincides with ruthless epidemiological statistics—cardiovascular diseases are responsible for $46 \%$ of deaths, malignancies for a further $24.5 \%$ [14]. At the same time, overweight characterizes $36.4 \%$ of Poles and another $15.8 \%$ are obese [15]. Moreover, $54 \%$ struggle with hypertension, while $22 \%$ of adult Poles consult a doctor due to musculoskeletal diseases [16]. Piekutowska et al. partially attribute this state of things to the inefficiency of the previous actions aimed at promoting LTPA and preventing obesity in Poland [17]. However, designing an adequate policy mix requires good recognition of PA across various social sections [18].

The objective of this paper is to provide an in-depth description of insufficient PA in Poland, as well as an examination of some of its correlates. By employing econometric modeling, it will support the public health policy, for instance in designing targeted pro-health campaigns as well as measures aimed at reducing the inequality in health status.

\section{Materials and Methods}

\subsection{Dataset}

The survey was commissioned by the Ministry of Sport and Tourism of the Republic of Poland and conducted by GfK Polonia [19]. It is an International Physical Activity Questionnaire (IPAQ) compatible, computer-assisted personal interview run every six months since early 2014 . A representative sample of adult Poles (aged 15-69) are asked about their physical activity (type, frequency, intensity), as well as various demographic and socioeconomic characteristics. The data are available for three out of four waves of the interviews.

Each wave examined approximately 1000 respondents, although this is a bit insufficient to draw robust conclusions regarding several cross-sections of the data. However, as we analyze cross-regional datasets measured in close intervals, questionnaires do not differ significantly and activity distributions among the first seven deciles of respondents across waves are similar, so we decided to pool the data from consecutive waves. The pooled database consists of 3056 records, out of which 1260 respondents were described as low physical activity (0-600 MET-min/week during seven days prior to the day of survey): 715 with literally no activity (0 MET-min/week) and 545 with a positive but insufficient total amount of activity (1-600 MET-min/week). According to the IPAQ guidelines, only activity lasting at least 10 min without interruption was recorded. Moreover, cases of unreasonably high total physical effort (over $16 \mathrm{~h}$ ) should be excluded from the analysis. Similarly, for the respondents who declared daily effort of one type of over $3 \mathrm{~h}$ records are automatically corrected to $3 \mathrm{~h}$. As a result, 11 unreliable observations were dropped. The final subsample contains 1260 low physical activity respondents, who are the subject of our analysis (Table 1).

IPAQ-compatibility of the Polish survey allows for international comparisons of the results all over the world. We use its long version [20]. The questionnaire distinguishes between LTPA (including: vigorous activity (VPA), moderate activity (MPA), and recreational walking) and transportation-related PA (walking or cycling from one place to another). We decided to include types of PA that contribute to meeting the WHO recommendations and are a result of respondents' voluntary decisions. The descriptive statistics of physical effort are converted into average energy expenditure of each activity in MET (MET unit corresponds to $\mathrm{O}_{2}$ consumption during rest and equals to $3.5 \mathrm{~mL} \mathrm{O} / 2 \mathrm{~kg}$ of 
the body mass per minute), according to a formula (each minute of activity equals to: VPA-8.0 MET, MPA—4.0 MET, walking—3.3 MET, cycling—6.0 MET).

Table 1. The sample structure.

\begin{tabular}{ccccccccc}
\hline $\begin{array}{c}\text { Age } \\
\text { Group }\end{array}$ & $\begin{array}{c}\text { Male } \\
\text { Wave 1 }\end{array}$ & $\begin{array}{c}\text { Male } \\
\text { Wave 2 }\end{array}$ & $\begin{array}{c}\text { Male } \\
\text { Wave 3 }\end{array}$ & $\begin{array}{c}\text { Male } \\
\text { Total }\end{array}$ & $\begin{array}{c}\text { Female } \\
\text { Wave 1 }\end{array}$ & $\begin{array}{c}\text { Female } \\
\text { Wave 2 }\end{array}$ & $\begin{array}{c}\text { Female } \\
\text { Wave 3 }\end{array}$ & $\begin{array}{c}\text { Female } \\
\text { Total }\end{array}$ \\
\hline $15-29$ & 29 & 40 & 29 & 358 & 24 & 19 & 28 & 329 \\
$30-39$ & 48 & 45 & 37 & 295 & 36 & 29 & 40 & 290 \\
$40-49$ & 40 & 25 & 37 & 229 & 30 & 27 & 30 & 226 \\
$50-59$ & 43 & 44 & 45 & 245 & 42 & 39 & 40 & 265 \\
$60-69$ & 42 & 55 & 63 & 353 & 82 & 86 & 86 & 466 \\
Total & 202 & 209 & 211 & 622 & 214 & 200 & 224 & 638 \\
\hline
\end{tabular}

By multiplying the frequency of activity per week and the effort, we obtain the sum of energy expenditures for each activity. After summarizing over all types of PA, we are able to assign the respondents into low, moderate or high physically active categories. Low physically activity: 0-600 MET-min/week, moderate: 601-1500 MET-min/week, high: 1501 and more MET-min/week. Despite controversies [21], these thresholds refer to all age groups, as in the original IPAQ questionnaire [22,23]. The low physical activity group is in the limelight of the analysis. For further analysis we find it useful to distinguish between individuals completely inactive and those whose PA is insufficient to meet the WHO guidelines [22]. Henceforth, we use notions of inactive for individuals with 0 MET-min/week of PA and insufficiently active for those with 1-600 MET-min/week of PA. These two categories contrasted with the sufficiently active group, with over 600 MET-min/week.

\subsection{Methods}

Being fully aware of the limitations arising from self-assessment of physical activity [21,22], we constructed a logistic regression. Its binary dependent variable (low physical activity) denotes 1 for respondents whose physical effort per week does not exceed 600 MET-min and 0 otherwise, so as to examine demographic and socioeconomic variables correlated with insufficient activity. The original set of explanatory variables covers: gender (male, female), age (15-29, 30-39, 40-49, 50-59, 60-69), household size (1, 2, 3, 4, 5 and more members), household life phase (eight categories: students cohabiting with parents, workers cohabiting with parents, young non-cohabiting households, families with youngest child aged: 0-6/7-14/15-25, senior working/retired households), professional status (executives or owners, high-level white-collar workers, low-level white-collar workers, qualified blue-collar worker, non-qualified blue-collar worker, farmer, unemployed, homemaker, pupil/student, pensioner or old-age pensioner), socioeconomic status (SES; upper middle class, middle class, lower middle class and skilled working class, working class, non-working class), educational level (higher, secondary, vocational, primary education), Internet use (frequent, rare, never), place of residence (urban areas with over $500 \mathrm{~K}$ inhabitants, urban areas with $50 \mathrm{~K}-500 \mathrm{~K}$ inhabitants, urban areas with less than $50 \mathrm{~K}$ inhabitants, rural areas) and country region (five macroregions of Poland). Except for the profession and SES, all the questions were asked directly. Profession is classified by the survey company into one of the abovementioned categories on the basis of undisclosed questions. Similarly, SES is an artificial variable representing joint income, educational level and profession. In the descriptive analysis we include all the available characteristics while their potential overlapping is tested in the statistical analysis section.

As we use a representative micro-database (for each respondent we have a detailed set of characteristics and an analytical weight reflecting how strong the representation of the respondent's characteristics in the society is), additional statistical calculations supplement the econometric modeling. While the former presents the relative frequency of physical inactivity and insufficient physical activity among Polish adults, the latter analyzes correlations between a wide range of demographic and socioeconomic characteristics, and insufficient physical activity. The scientific aim notwithstanding, such analysis is the first stage in designing effective policy towards increasing of 
physical activity. Statistical calculations were carried out with SPSS ${ }^{\circledR}$ Statistics Version 21 software $\left(\mathrm{IBM}^{\circledR}\right.$, Armonk, NY, USA) econometric modeling-with STATA 14 software (StataCorp LP, Lakeway Drive, TX, USA).

\section{Results}

\subsection{Descriptive Analysis}

The survey reveals the scale of physical inactivity in Poland: almost one in four adults declares complete inactivity, while over two in five make too little physical effort to meet the WHO guidelines (Table 2). The distribution of PA effort among the insufficiently active is roughly even-the mean effort for this group equals $350 \mathrm{MET}-\mathrm{min} /$ week $(\mathrm{SD}=156)$. Cross-sectional analysis of non-active and insufficiently active respondents delivers robust results-except for gender, the $p$-value remains below the level of 0.01 .

Table 2. Structure of physical inactivity and low activity in Poland (\%).

\begin{tabular}{|c|c|c|c|c|}
\hline \multicolumn{2}{|r|}{ Variables ( $p$-Value) } & \multirow{2}{*}{$\begin{array}{c}\begin{array}{c}\text { Inactive } \\
(0 \mathrm{MET}-\mathrm{min} / \text { week) } \\
n=715\end{array} \\
24.0 \\
\end{array}$} & \multirow{2}{*}{$\begin{array}{c}\text { Insufficiently Active } \\
\text { (1-600 MET-min/week) } \\
\boldsymbol{n = 5 4 5}\end{array}$} & \multirow{2}{*}{$\begin{array}{c}\text { Low Physically Active } \\
\text { (0-600 MET-min/week) } \\
n=\mathbf{1 2 6 0}\end{array}$} \\
\hline & total & & & \\
\hline Gender & female & 23.6 & 17.3 & 40.9 \\
\hline$p=0.225$ & male & 24.5 & 16.9 & 41.3 \\
\hline \multirow{5}{*}{$\begin{array}{l}\text { Age group } \\
p=0.005\end{array}$} & $15-29$ & 14.1 & 10.5 & 24.6 \\
\hline & $30-39$ & 21.5 & 18.4 & 39.8 \\
\hline & $40-49$ & 30.3 & 15.1 & 45.4 \\
\hline & $50-59$ & 29.0 & 18.9 & 47.9 \\
\hline & $60-69$ & 28.4 & 22.5 & 50.9 \\
\hline \multirow{5}{*}{$\begin{array}{l}\text { Household size } \\
\qquad p=0.001\end{array}$} & 1 & 23.3 & 19.6 & 42.8 \\
\hline & 2 & 25.7 & 22.1 & 47.8 \\
\hline & 3 & 23.4 & 16.2 & 39.6 \\
\hline & 4 & 20.6 & 15.9 & 36.5 \\
\hline & 5 and over & 26.4 & 13.8 & 40.2 \\
\hline \multirow{8}{*}{$\begin{array}{l}\text { Household life phase } \\
\qquad p=0.000\end{array}$} & studying, living with parents & 11.5 & 6.5 & 18.0 \\
\hline & working, living with parents & 16.0 & 14.6 & 30.5 \\
\hline & $\begin{array}{l}\text { non-senior, working, childless, } \\
\text { separate living }\end{array}$ & 18.9 & 14.4 & 33.3 \\
\hline & household with children 0-6 & 20.0 & 15.5 & 35.5 \\
\hline & household with children 7-14 & 25.7 & 16.4 & 42.1 \\
\hline & household with children $15-25$ & 31.0 & 19.3 & 50.3 \\
\hline & senior, working & 28.8 & 19.3 & 48.1 \\
\hline & senior, not working & 27.6 & 23.0 & 50.6 \\
\hline \multirow{4}{*}{$\begin{array}{l}\text { Education } \\
p=0.000\end{array}$} & primary & 43.0 & 19.6 & 62.5 \\
\hline & vocational & 31.6 & 19.9 & 51.5 \\
\hline & secondary & 19.1 & 19.3 & 38.4 \\
\hline & higher & 15.4 & 17.2 & 32.6 \\
\hline \multirow{3}{*}{$\begin{array}{l}\text { Use of Internet } \\
\quad p=0.000\end{array}$} & everyday & 14.0 & 15.0 & 29.0 \\
\hline & rare & 26.3 & 16.8 & 43.1 \\
\hline & never & 34.1 & 19.7 & 53.9 \\
\hline \multirow{10}{*}{$\begin{array}{c}\text { Profession } \\
p=0.000\end{array}$} & managers, executives, owners & 18.0 & 15.8 & 33.9 \\
\hline & high-level professionals & 20.6 & 17.0 & 37.6 \\
\hline & low-level professionals & 15.0 & 9.4 & 24.4 \\
\hline & qualified blue-collar jobs & 23.2 & 17.8 & 40.9 \\
\hline & non-qualified blue-collar jobs & 20.7 & 16.8 & 37.5 \\
\hline & farmers & 44.5 & 21.2 & 65.6 \\
\hline & homemakers & 25.1 & 20.5 & 45.6 \\
\hline & students & 13.1 & 6.3 & 19.3 \\
\hline & pensioners & 27.6 & 21.8 & 49.4 \\
\hline & unemployed & 23.8 & 14.8 & 38.5 \\
\hline \multirow{5}{*}{$\begin{array}{l}\text { Socioeconomic status } \\
\qquad p=0.000\end{array}$} & upper middle class & 14.3 & 14.4 & 28.6 \\
\hline & middle class & 16.7 & 16.9 & 33.7 \\
\hline & lower middle class and skilled working class & 23.9 & 16.9 & 40.8 \\
\hline & working class & 29.6 & 17.6 & 47.2 \\
\hline & not working & 36.2 & 19.5 & 55.7 \\
\hline \multirow{4}{*}{$\begin{array}{l}\text { Place of residence } \\
\quad p=0.000\end{array}$} & rural areas & 31.7 & 17.5 & 49.3 \\
\hline & urban areas, less than $50 \mathrm{~K}$ inhabitants & 25.1 & 16.9 & 42.0 \\
\hline & urban areas, $50 \mathrm{~K}-500 \mathrm{~K}$ inhabitants & 17.2 & 16.3 & 33.5 \\
\hline & urban areas, over $500 \mathrm{~K}$ inhabitants & 10.6 & 17.7 & 28.3 \\
\hline \multirow{5}{*}{$\begin{array}{c}\text { Region } \\
p=0.003\end{array}$} & central & 18.6 & 20.3 & 38.9 \\
\hline & north-eastern & 29.4 & 18.5 & 48.0 \\
\hline & north-western & 21.3 & 16.5 & 37.8 \\
\hline & south-western & 26.0 & 14.2 & 40.2 \\
\hline & south-eastern & 27.3 & 17.4 & 44.7 \\
\hline
\end{tabular}

Shares in category education are calculated for age groups 30 and over. $p$-Value reflects a significance of difference across categories for a given factor. 
As individuals age and the share of inactivity increases, so does the share of low physical activity. The respective proportions double between the youngest and the oldest age group. Out of all types of effort, walking (regardless of aim) is the most popular one among the insufficiently active, and does not lose its popularity among older groups. The share of transportation walkers saturates at the level of $50 \%$, while recreational walking regains popularity among those who are $50+$. By contrast, commutative cycling, MPA and VPA decrease with age (Figure 1).

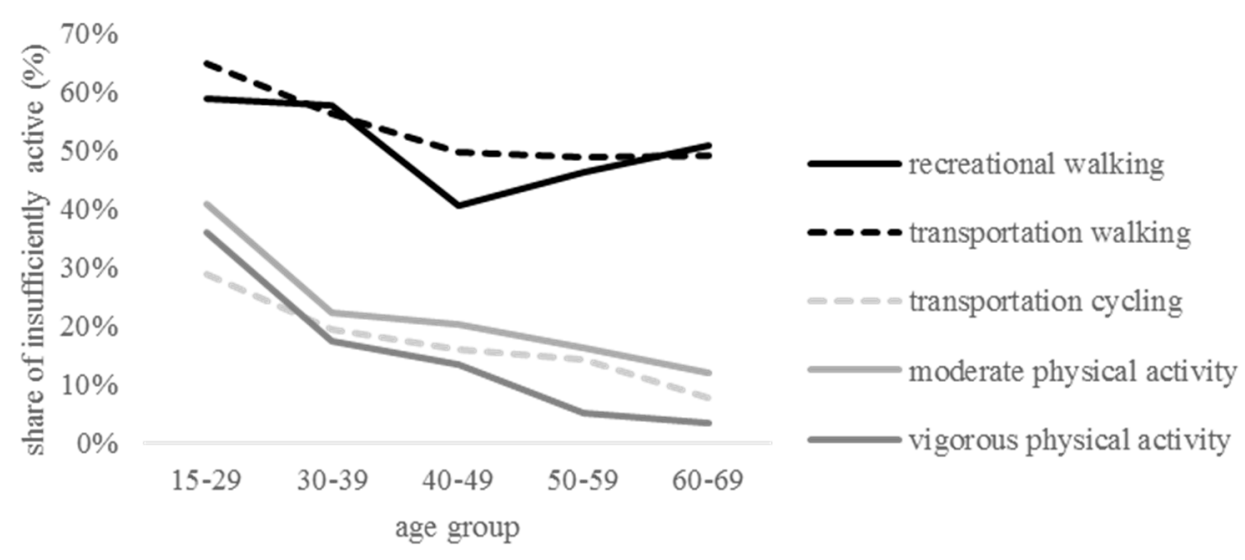

Figure 1. Share of insufficiently active taking up physical activity, by age groups and type of physical activity.

The share of the non-active is low among individuals living with parents and much lower than among non-senior childless households. As families expand and children grow, parents gradually reduce their PA. The shares for parents of adult children are similar to senior households. Recreational walking happens more often among students cohabiting with parents, non-senior childless households, as well as parents of the youngest children. Also MPA is more frequent among households with children (12\%-21\%). VPA gains popularity in non-senior childless households $(5 \%)$, and so does cycling (9\%). Household size, even though significant, does not exhibit a clear pattern of physical inactivity.

White-collar workers are in general more active than blue-collar workers, with the exception of non-qualified blue-collar workers, whose activity pattern is similar to high-level professionals. An extreme case of inactivity is found among farmers. Physical and economic inactivity go together: the unemployed, homemakers and pensioners exhibit too little physical effort more often than their working counterparts.

In general, the higher the level of education, the higher the probability of fulfilling the WHO recommendations. Walking is more frequent among people with primary education ( $72 \%$, comparing to ca. $50 \%$ in other groups), cycling is a domain of secondary education holders $(6 \%$, comparing to $0 \%$ in tertiary, $3 \%$ in primary and $4 \%$ in vocational), while interest in MPA increases with educational level (from $7 \%$ among primary to $18 \%$ among tertiary education holders).

Activity is a monotonically increasing function of socioeconomic status. Even though the overall activity pattern is clear, there is none when it comes to the types of activity. The only exception in this case is MPA, significantly more frequent among the middle class (17\%), and cycling, characteristic for the lower middle class and skilled working class $(8 \%)$.

Low PA is much more frequently observed among rural than urban dwellers. One in three does not engage in any activity, while among the inhabitants of Poland's five biggest cities (over $500 \mathrm{~K}$ inhabitants) it happens in one in 10 cases. The smaller the place of residence, the more common the occurrence of PA deficits. Lack of recreational walking was typical of rural dwellers (63\%; it is a slightly more popular form of PA among urban dwellers: $52 \%-57 \%$ ), while the reverse applies to walking for the purpose of transportation ( $48 \%$ vs. $56 \%-61 \%)$. MPA is taken up more often in bigger cities $(18 \%)$ 
and in rural areas (14\%) than in towns (11\%-12\%), while cycling is most common in rural areas $(9 \%)$ and smaller towns (5\%). In cities, the share of cyclists in negligible. Neither the region of residence itself nor its cross-section with the place of residence show any patterns.

\subsection{Statistical Analysis}

The descriptive analysis confirms several intuitions on regularities among those with low physical activity in Poland. However, it is unable to identify which factors affect their low activity. In the next step we examine whether the existing concentration of insufficient activity is statistically significant. In order to answer the question, we use logistic regression $(n=3028)$. The Hosmer-Lemeshow test indicates that the model is well fitted (Table 3).

Table 3. Logit estimation of physical insufficient activity in Poland.

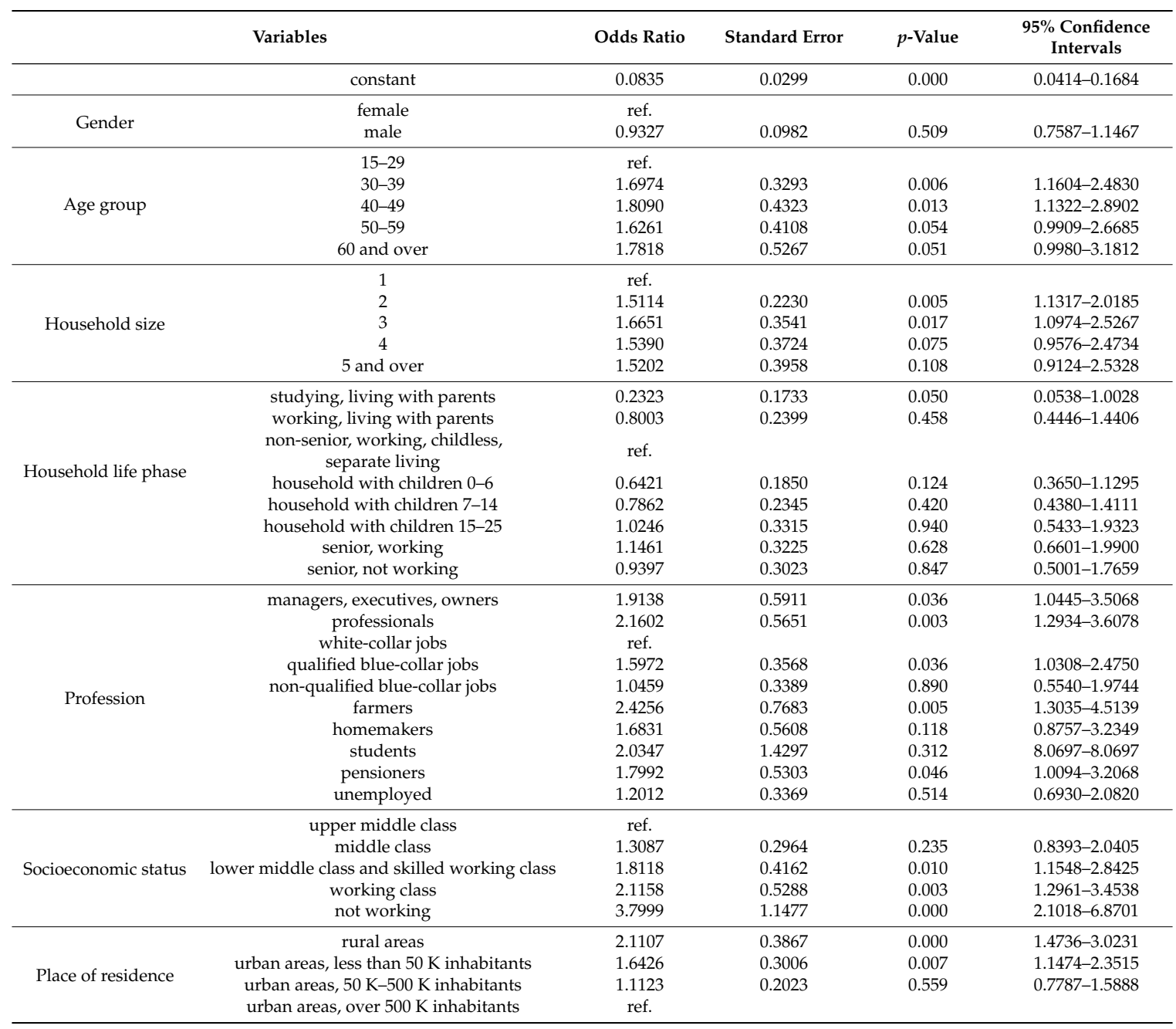

$n=3028$; ref. - reference category; McFadden's $R$-squared: 0.0757; Hosmer-Lemeshow test: 0.5943.

Contrary to the existing literature, gender does not significantly influence insufficient physical activity in Poland. Only partial results are obtained by contrasting age groups. Compared to the youngest age group (15-29), the middle-agers are more prone to low PA by $70 \%(30-39)$ and $80 \%$ (40-49). A similar proportion holds for individuals in their 50s, 60s and older; however, the significance is only slightly above the 0.05 threshold. Adding interactions of gender and age group fails to deliver any added value in uncovering patterns of physical inactivity (lack of statistical significance).

The size of the household is more significant than the household life phase. When compared with one-person households, each marginal member increases the odds of insufficient activity-the 
second one by $51 \%$, the third by $67 \%$. For four and more members, however, statistical significance of the effect decreases. Among household types, the only significant one was the status of a student cohabiting with his or her parents. In this group the odds of insufficient activity decreased by over $72 \%$ when confronted with a non-senior, economically active childless household. The non-significance of various family categories is robust, regardless of its character.

Similarly, only several professions are significantly correlated with low physical activity. The strongest relation applies to farmers whose odds of insufficient activity-compared to white-collar workers-are almost 2.5 times higher. For professionals this ratio is 2.2. Also, the position of an executive, manager or owner and a skilled blue-collar worker affects the low PA to some extent-the respective ratios are 1.9 and 1.6 times (compared to a white-collar worker). Among the economically inactive, the only significant category is the pensioners with an odds ratio of almost 1.8 compared to the reference group.

According to the model, not the demographic variables, but socioeconomic variables are of extreme importance when it comes to identifying the correlates of insufficient physical activity in Poland. The lower the socioeconomic status, the higher the odds are of insufficient activity and this seems to be a very robust conclusion. Compared to the upper middle class, the lower middle class and skilled working class are characterized by over $80 \%$ higher odds of insufficient activity. For working class members this proportion exceeds $110 \%$, while for the non-working it is almost three times as high. Similarly, strong conclusions arise if the place of residence is included as a regressor. Rural area dwellers and town dwellers have visibly higher odds of insufficient physical activity than inhabitants of big cities—by over $110 \%$ and $60 \%$, respectively.

\section{Discussion}

The general purpose of this paper was to characterize insufficient physical activity among Polish adults and identify its correlates. This seems to be an urgent issue as more than $40 \%$ of citizens make smaller physical efforts than the level that would keep them healthy, according to the WHO standards [7]. Over half of those with low physical activity declare literally no activity, either LTPA or transportation-induced. Besides, $25 \%$ of adult Poles are non-walkers, which is one of the highest proportions among EU member states [9]. In this light, a high risk of NCDs is justified. In a country of over 37 million inhabitants, these shares translate into millions of people at risk of NCDs.

Although the increase in inactivity in Poland (3.3 percentage points over the period of 2009-2013) is a part of an international trend [9], there are several factors suggesting that the trend of physical inactivity will strengthen, unless the public policy becomes more successful. Firstly, provided the age-specific patterns of activity remain stable, the population aging in Poland [24] should, on average, reduce activity among individuals. Until now senior citizens have not been convinced to be physically active, even though they retire relatively early [25] and are at low risk of poverty [26]. As indicated by European Agency for Safety and Health at Work (EU-OSHA), PA should become an element of the actions aimed at preventing early retirement and increasing employability [27], including developing a health prevention profile of an employee with standard tests for PA measurement or annual PA level tests for senior citizens recorded in the national health monitoring system. Moreover, keeping in mind their complaints on subjective health status [28], considering regular, moderate PA could—at least to some extent-solve their problems $[29,30]$.

Secondly, the adverse trend will be influenced by the decreasing activity of the youngest age groups. Existing literature suggests that physical inactivity among today's children is a massive problem [31,32], mainly because a sedentary lifestyle and avoidance of compulsory physical education classes result in poor behavioral patterns in later phases of life [33]. The first signals of inactivity are observed in the dispersion in our subsample: while the overall performance of the youngest age group is relatively good, we identify a share of those avoiding any PA, even walking. If these patterns are at least partially transferable between generations—as confirmed by other researchers [34,35] - the intervention should not be limited to children only. 
Thirdly, physical activity in Poland is frequently performed as long as various duties allow for it, but additional professional or family commitments reduce physical effort. Moreover, even when commitments are reduced in scale, low PA levels persist. This conclusion is confirmed by the Polish Public Opinion Research Center survey [36]: Poles do not perceive physical activity as a desired form of free-time activity. Sedentary rest dominates, going for a walk is undertaken occasionally $(24 \%)$, and a physical workout is even less popular (11\%). Even though Poles complain about their lack of free time, they would spend it neither on sport (7\%), nor going for a walk or cycling $(4 \%)$.

Another issue worth mentioning is the notable variation in physical effort between cross-sectional subsamples. The most physically active subsections consist of less than $20 \%$ of low physically active, while for the least active subsections the respective share exceeds $60 \%$, posing a threat to social cohesion in this field. In many cases, the decision about physical activity is affected by financial availability. This argument seems to be well justified by the preference of transportation walking among the economically active and students, as well as cycling among rural area dwellers. In our research, the latter are characterized by lower PA and the logistic regression confirms the robustness of this relationship. This conclusion is in line with previous research indicating that, among rural area dwellers, the probability of meeting the recommended PA amount is significantly lower than among urban dwellers [37,38]. Moreover, city dwellers show a much higher interest in MPA than rural area dwellers (often working in urban areas), and especially town dwellers. These decisions are probably shaped by transaction costs, i.e., financial and time availability of various sport infrastructures, namely football fields, fitness clubs, cycle paths, playgrounds or simply parks and forests. Those are unevenly distributed in Poland [39]. As Parks, Castro, and King prove [40], being too far from activity facilities, lower social support, and less pavements are usually major barriers for living actively in rural areas. Unfortunately, it would also confirm that physical activity is affected by social inequalities.

However, financial constraints do not justify the walking patterns. Sport is generally perceived in Poland as an issue separate from health and not as its significant element. This lack of awareness is especially visible when physical inactivity among the poorly educated and those with financial constraints is analyzed. The better educated are more prone to follow the rules of a healthy lifestyle, take care of their health and control it regularly, exercise, and generally spend time actively. They are also more educated as to threats to physical and psychological well-being, and are able to avoid negative consequences of these states and minimize their adverse effects [41]. The existing literature suggests that, to some extent, individuals change their unhealthy habits when they are made aware of their consequences [42]. This observation finds confirmation in our dataset. Among adults with primary or vocational education, the share of inactivity is twice as high compared with people holding higher or secondary degrees. Moreover, white-collar workers are more active than blue-collar workers (in the details it is not as clear-cut $[43,44]$ ) and especially farmers, in whose case technological changes in their work conditions have taken place, but their physical activity has not been adjusted yet $[45,46]$. Economic inactivity (except for students) and the resulting free time are not reflected in their PAs. This case is ambiguous as the unemployed have obvious difficulties in fulfilling their pro-health aims (unable to purchase pro-health goods and services). However, it is not an obstacle when it comes to either leisure or transportation walking. This finding is confirmed also by Pampel, Krueger, and Denney [47]. In this context, the socioeconomic status, which has been strongly confirmed in the modeling procedure, is even more distinctive. Higher education, high professional status and related incomes go together with the share of the sufficiently active and the duration of LTPA [48,49]. High SES is associated with caring for one's own health, while a professional career demands good fitness, stress resilience, and a slim figure [50,51]. By contrast, low SES considerably decreases the awareness of health issues and motivation, as well as imposes financial constraints [52]. Empirically, among individuals with lower occupational status, LTPA is crowded out by physical activity at work, during household chores and in commuting [53,54]. However, it is worth emphasizing that neither education nor profession or status provide enough physical effort. 
This study sheds a new light on physical inactivity in Poland. However, there are several limitations that reduce the robustness of our conclusions. Firstly, what would increase our knowledge in physical activity patterns is a panel dataset. It would show the actual changes in physical activity when a life event occurs. It would also allow us to distinguish between real changes and cohort effects. The crucial issue in this context is whether individuals reduce their effort as time goes by or if they are time-consistent. Each pattern requires slightly different means. Secondly, the sample of 1000 respondents has limited robustness when drawing conclusions. Thirdly, declaration and self-assessment are prone to exaggeration, which we assume to be negligible. This factor could be irrelevant if objective measurements replaced the declarations.

\section{Conclusions}

Increasing physical activity, particularly LTPA, is a priority task for public health policy worldwide. In Poland, there should be special attention paid to it because as many as $40 \%$ of its citizens (analyzed in terms of LTPA and transportation-related PA) do not meet the WHO health standards (including more than $50 \%$ declaring literally no activity). In a country of over 37 million inhabitants, these shares translate into millions of people at risk of NCDs. As the consequences of complete inactivity are substantial both in terms of financial costs and untapped potential, the preventive actions should be primarily aimed at sport-averse individuals. Insufficient activity is most frequently observed among inhabitants of rural areas and town dwellers, those with a poor educational profile, and those limited labor market opportunities (economically inactive, farmers). These groups should be covered by promotional actions first. However, even high socioeconomic status (e.g., managers and professionals) does not prevent insufficient activity completely.

PA is rarely perceived as an attractive leisure-time activity; therefore, educational programs should be aimed at raising the awareness of LTPA. For groups at risk of inactivity with limited knowledge and financial constraints, basic forms of activity should be promoted, and that includes walking, Nordic walking or jogging. These disciplines seem to be effective also in the case of elder individuals.

Acknowledgments: The research was conducted by GfK Polonia and commissioned by the Ministry of Sport and Tourism of the Republic of Poland. The authors want to thank Piotr Bartkiewicz for useful comments on the first version of the manuscript.

Author Contributions: Elżbieta Biernat conceived and designed the experiments; Elżbieta Biernat performed the experiments; Sonia Buchholtz analyzed the data; Elżbieta Biernat and Sonia Buchholtz contributed reagents/materials/analysis tools; Elżbieta Biernat and Sonia Buchholtz wrote the paper.

Conflicts of Interest: The authors declare no conflict of interest.

\section{Abbreviations}

The following abbreviations are used in this manuscript:

PA

NCD

WHO

LTPA

IPAQ

VPA

MPA

Physical Activity

Noncommunicable Disease

World Health Organizations

Leisure-Time Physical Activity

International Physical Activity Questionnaire

Vigorous Physical Activity

EU-OSHA European Agency for Safety and Health at Work

\section{References}

1. Morris, J.N.; Heady, J.A.; Raffle, P.A.B.; Roberts, C.G.; Parks, J.W. Coronary heart disease and physical activity of work. Lancet 1953, 262, 1053-1057. [CrossRef]

2. Ekelund, U.; Ward, H.A.; Norat, T.; Luan, J.; May, A.M.; Weiderpass, E.; Sharp, S.S.; Overvad, K.; Nautrup Østergaard, J.; Tjønneland, A.; et al. Physical activity and all-cause mortality across levels of overall and abdominal adiposity in European men and women: The European Prospective Investigation into Cancer and Nutrition Study (EPIC). Am. J. Clin. Nutr. 2015, 101, 613-621. [CrossRef] [PubMed] 
3. Bauman, A.; Ainsworth, B.E.; Sallis, J.F.; Hagströmer, M.; Craig, C.L.; Bull, F.; Pratt, M.; Venugopal, K.; Chau, J.Y.; Sjostrom, M. The descriptive epidemiology of sitting: A 20-country comparison using the International Physical Activity Questionnaire (IPAQ). Am. J. Prev. Med. 2011, 41, 228-235. [CrossRef] [PubMed]

4. Haskell, W.L.; Lee, I.M.; Pate, R.R.; Powell, K.E.; Blair, S.N.; Franklin, B.A.; Macera, C.A.; Heath, G.W.; Thompson, P.D.; Bauman, A. Physical activity and public health. Updated recommendation for adults from the American college of sports medicine and the American heart association. Circulation 2007, 116, 1081-1093. [PubMed]

5. Rahl, R.L. Physical Activity and Health Guidelines: Recommendations for Various Ages, Fitness Levels, and Conditions from 57 Authoritative Sources; Human Kinetics Publishers: Champaign, IL, USA, 2010.

6. American College of Sport Medicine. ACSM's Guidelines for Exercise Testing and Prescription, 8th ed.; Lippincott Williams \& Wilkins: Baltimore, MD, USA, 2010.

7. World Health Organization. Global Recommendations on Physical Activity for Health; WHO Library Cataloguing-in-Publication Data: Geneva, Switzerland, 2010.

8. Katzmarzyk, P.T.; Janssen, I.; Ardern, C.I. Physical inactivity, excess adiposity and premature mortality. Obes. Rev. 2003, 4, 257-290. [CrossRef] [PubMed]

9. European Commission. Special Eurobarometer 412. Sport and Physical Activity; TNS Opinion \& Social: Brussels, Belgium, 2014.

10. Li, J.; Loerbroks, A.; Angerer, P. Physical activity and risk of cardiovascular disease: What does the new epidemiological evidence show? Curr. Opin. Cardiol. 2013, 28, 575-583. [CrossRef] [PubMed]

11. Holtermann, A.; Marott, J.L.; Gyntelberg, F.; Søgaard, K.; Suadicani, P.; Mortensen, O.S.; Prescott, E.; Schnohr, P. Does the benefit on survival from leisure time physical activity depend on physical activity at work? A prospective cohort study. PLoS ONE 2013, 8, e54548. [CrossRef] [PubMed]

12. Mynarski, W.; Grabara, M.; Nawrocka, A.; Niestrój-Jaworska, M.; Wołkowycka, B.; Cholewa, J. Physical recreational activity and musculoskeletal disorders in nurses. Med. PR 2014, 65, 181-188. [PubMed]

13. Biernat, E.; Piątkowska, M. Individual and environmental factors determining sedentary lifestyle of the polish population. Iran J. Public Health 2014, 43, 1033-1044. [PubMed]

14. Wojtyniak, B., Goryński, P., Moskalewicz, B., Eds.; Sytuacja Zdrowotna Ludności Polski i jej Uwarunkowania (Health Status of the POLISH Population and Its Determinants); Narodowy Instytut Zdrowia Publicznego-Państwowy Zakład Higieny: Warszawa, Poland, 2012.

15. Central Statistical Office of Poland. Stan Zdrowia Ludności Polski w 2009 r. Informacje i Opracowania Statystyczne (The Health of the Polish Population in 2009. Statistical Information and Reports); GUS: Warszawa, Poland, 2011.

16. Medicover Raport Zdrowia. Praca. Zdrowie. Ekonomia. Perspektywa 2009-2013 (Work Health Economics Perspective 2009-2013). Available online: http:/ / www.medicover.pl/261,1389,313,raport-praca-zdrowieekonomia-perspektywa-2009-2013,news.htm (accessed on 21 April 2016).

17. Piekutowska, S.; Kanicka, M.; Pogorzelska, P.; Charkiewicz, A.E.; Kanicki, T.; Szpak, A. Rola kampanii społecznych w promowaniu zachowań sprzyjających zdrowiu wśród studentów białostockich Uczelni (Role of social campaigns in promoting health behavior among college students in Białystok). Hygeia Public Health 2013, 48, 500-504.

18. Bartholomew, K.L.; Parcel, G.S.; Kok, G.; Gottlieb, N.H.; Fernández, M.E. Planning Health Promotion Programs: An Intervention Mapping Approach; Jossey-Bass: San Francisco, CA, USA, 2006.

19. Ministry of Sport and Tourism of the Republic of Poland. Aktywność Fizyczna Polaków (The Physical Activity of Poles); Ministry of Sport and Tourism of the Republic of Poland: Warszawa, Poland, 2016.

20. Biernat, E. International physical activity questionnaire-Polish long version. Pol. J. Sport Med. 2013, 29, 1-15.

21. Heesch, K.C.; van Uffelen, J.G.Z.; Hill, R.L.; Brown, W.J. What do IPAQ questions mean to older adults? Lessons from cognitive interviews. Int. J. Behav. Nutr. Phys. 2010, 5. [CrossRef] [PubMed]

22. Rzewnicki, R.; Vanden Auweele, Y.; de Bourdeaudhuij, I. Addressing overreporting on the International Physical Activity Questionnaire (IPAQ) telephone survey with a population sample. Public Health Nutr. 2003, 6, 299-305. [CrossRef] [PubMed]

23. The IPAQ Group. Guidelines for Data Processing and Analysis of the International Physical Activity Questionnaire (IPAQ)—Short and Long Forms. Available online: http://www.ipaq.ki.se/ (accessed on 5 July 2016). 
24. European Commission. Ageing Report 2015. Economic and Budgetary Projections for the 28 EU Member States (2013-2060); European Economy: Brussels, Belgium, 2015.

25. Organisation for Economic Co-Operation and Development (OECD). Pensions at a Glance 2013: OECD and G20 Indicators; OECD Publishing: Paris, France, 2013.

26. Zaidi, A. Life Cycle Transitions and Vulnerabilities in Old Age: A Review; UNDP Human Development Report Office 2014. Available online: http://www.hdr.undp.org/sites/default/files/hdr_2014_zaidi_final.pdf (accessed on 29 March 2016).

27. European Agency for Safety \& Health at Work. Available online: http://www.osha.europa.eu/en/healthyworkplaces-campaigns /2016-17-campaign-healthy-workplaces-all-ages (accessed on 28 July 2016).

28. Central Statistical Office of Poland. Jak Się Żyje Osobom Starszym w Polsce? (What Is the Quality of Life of the Seniors in Poland?); GUS: Warszawa, Poland, 2012.

29. Penedo, F.J.; Dahn, J.R. Exercise and well-being: A review of mental and physical health benefits associated with physical activity. Curr. Opin. Psychiatry 2005, 18, 189-193. [CrossRef] [PubMed]

30. Procter-Gray, E.; Leveille, S.G.; Hannan, M.T.; Cheng, J.; Kane, K.; Li, W. Variations in community prevalence and determinants of recreational and utilitarian walking in older age. J. Aging Res. 2015. [CrossRef] [PubMed]

31. Mazur, J., Ed.; Status Materialny Rodziny i Otoczenia a Samopoczucie i Styl Życia Młodzieży 15-letniej (Material Status of the Family, Environment, and the Well-Being and lifestyle of the 15-year-old Teenagers); Instytut Matki i Dziecka: Warszawa, Poland, 2012.

32. Stupnicki, R.; Kulma, A.; Zygmunt, D.; Baśkiewicz, A. Physical activity of adolescents as assessed by IPAQ questionnaire. Z. Nauk. Wskfit 2014, 9, 69-74.

33. Kraut, A.; Melamed, S.; Gofer, D.; Froom, P. Effect of school age sports on leisure time physical activity in adults. The CORDIS study. Med. Sci. Sport Exerc. 2003, 35, 2038-2042. [CrossRef] [PubMed]

34. Fuemmeler, B.F.; Anderson, C.B.; Mâsse, L.C. Parent-child relationship of directly measured physical activity. Int. J. Behav. Nutr. Phys. 2011, 3. [CrossRef] [PubMed]

35. Hamilton, K.; White, K.M. Understanding parental physical activity: Meanings, habits, and social role influence. Psychol. Sport Exerc. 2010, 11, 275-285. [CrossRef]

36. Centrum Badania Opinii Społecznej (CBOS). Czas Wolny Polaków. Komunikat z Badań BS 133/2010 (Leasure Time of Poles. Research Bulletin BS 133/2010); CBOS: Warszawa, Poland, 2010.

37. Martin, S.L.; Kirkner, G.J.; Mayo, K.; Matthews, C.E.; Durstine, J.L.; Hebert, J.R. Urban, rural, and regional variations in physical activity. J. Rural Health 2005, 21, 239-244. [CrossRef] [PubMed]

38. Wilcox, S.; Castro, C.; King, A.C.; Housemann, R.; Brownson, R.C. Determinants of leisure time physical activity in rural compared with urban older and ethnically diverse women in the United States. J. Epidemiol. Community Health 2000, 54, 667-672. [CrossRef] [PubMed]

39. Central Statistical Office of Poland. Kultura Fizyczna w Polsce w Latach 2008-2010. Informacje $i$ Opracowania Statystyczne (The Physical Culture in Poland in 2008-2010. Information and Reports); GUS: Rzeszów, Poland, 2011.

40. Parks, S.E.; Housemann, R.A.; Brownson, R.C. Differential correlates of physical activity in urban and rural adults of various socioeconomic backgrounds in the United States. J. Epidemiol. Community Health 2003, 57, 29-35. [CrossRef] [PubMed]

41. Hawkins, S.A.; Cockburn, M.G.; Hamilton, A.S.; Mack, T.M. An estimate of physical activity prevalence in a large population-based cohort. Med. Sci. Sport Exerc. 2004, 36, 253-260. [CrossRef] [PubMed]

42. Lechner, L.; Bolman, C.; van Dijke, M. Factors related to misperception of physical activity in The Netherlands and implications for health promotion programmes. Health Promot. Int. 2006, 21, 104-112. [CrossRef] [PubMed]

43. Hu, G.; Pekkarinen, H.; Hänninen, O.; Yu, Z.; Tian, H.; Guo, Z.; Nissinen, A. Physical activity during leisure and commuting in Tianjin, China. Bull. World Health Organ. 2002, 80, 933-938. [PubMed]

44. Salmon, J.; Owen, N.; Bauman, A.; Schmitz, M.K.H.; Booth, M. Leisure-time, occupational, and household physical activity among professional, skilled, and less-skilled workers and homemakers. Prev. Med. 2000, 30, 191-199. [CrossRef] [PubMed]

45. Brumby, S.; Chandrasekara, A.; McCoombe, S.; Torres, S.; Kremer, P.; Lewandowski, P. Reducing psychological distress and obesity in Australian farmers by promoting physical activity. BMC Public Health 2011, 5. [CrossRef] [PubMed] 
46. Ding, D.; Sallis, J.F.; Hovell, M.F.; Du, J.; Zheng, M.; He, H.; Owen, N. Physical activity and sedentary behaviors among rural adults in Suixi, China: A cross-sectional study. Int. J. Behav. Nutr. Phys. 2011, 4. [CrossRef]

47. Pampel, F.C.; Krueger, P.M.; Denney, J.T. Socioeconomic disparities in health behaviors. Annu. Rev. Sociol. 2010, 36, 349-370. [CrossRef] [PubMed]

48. Kaleta, D.; Jegier, A. Predictors of inactivity in the working age population. Int. J. Occup. Med. Environ. Health 2007, 20, 175-182. [CrossRef] [PubMed]

49. Kahan, E.; Fogelman, Y.; Bloch, B. Correlations of work, leisure, and sports physical activities and health status with socioeconomic factors: A national study in Israel. Postgrad. Med. J. 2005, 81, 262-265. [CrossRef] [PubMed]

50. Biernat, E.; Tomaszewski, P. Association of socioeconomic and demographic factors with physical activity of males and females aged 20-69 years. Ann. Agric. Environ. Med. 2015, 22, 118-123. [CrossRef] [PubMed]

51. Zarotis, G.F.; Katsagolis, A.; Mitrotasios, M. Free time and its alteration tendencies. Stud. Phys. Cult Tour. 2007, 14, 182.

52. Kaleta, D.; Makowiec-Dabrowska, T.; Jegier, A. Lifestyle index and work ability. Int. J. Occup. Med. Environ. Health 2006, 19, 170-177. [CrossRef] [PubMed]

53. Fogelman, Y.; Bloch, B.; Kahan, E. Assessment of participation in physical activities and relationship to socioeconomic and health factors. The controversial value of self-perception. Patient Educ. Couns. 2004, 53, 95-99. [CrossRef]

54. Kaleta, D.; Jegier, A. Occupational energy expenditure and leisure-time physical activity. Int. J. Occup. Med. Environ. Health 2005, 18, 351-356. [PubMed]

(C) 2016 by the authors; licensee MDPI, Basel, Switzerland. This article is an open access article distributed under the terms and conditions of the Creative Commons Attribution (CC-BY) license (http://creativecommons.org/licenses/by/4.0/). 